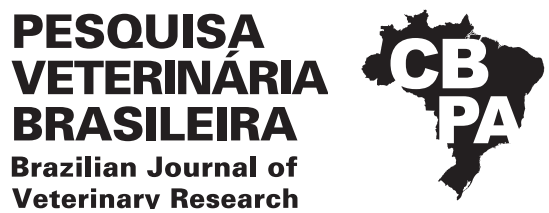

Pesq. Vet. Bras. 42:e07014, 2022

DOI: 10.1590/1678-5150-PVB-7014

Original Article

Veterinarv Research

ISSN 0100-736X (Print)

Livestock Diseases

ISSN 1678-5150 (Online)

\title{
Retrospective study of poxviruses diagnosed in cattle from Goiás State, Brazil (2010-2018) ${ }^{1}$
}

\author{
Lorena F. Silva ${ }^{2}$, Antônio A. Leal ${ }^{3}$, Paulo H.J. Cunha ${ }^{4}$, Juliana F. Cargnelutti ${ }^{5}$, \\ Eduardo F. Flores ${ }^{5}$ (D), Thiago B. Almeida ${ }^{6}$ and Fabiano J.F. Sant'Ana ${ }^{6 *}$ (D)
}

\begin{abstract}
Silva L.F., Leal A.A., Cunha P.H.J., Cargnelutti J.F., Flores E.F., Almeida T.B. \& Sant'Ana F.J.F. 2022. Retrospective study of poxviruses diagnosed in cattle from Goiás State, Brazil (2010-2018). Pesquisa Veterinária Brasileira 42:e07014, 2022. Laboratório de Diagnóstico Patológico Veterinário, Universidade de Brasília, SRB, Área Especial, Galpão 04, Granja do Torto, Brasília, DF 70636-020, Brazil. E-mail: santanafjf@yahoo.com

A retrospective study of poxvirus infections diagnosed in cattle from Goiás state (G0), Brazil, from 2010 to 2018, was performed. All cases have been investigated by the GO Official Veterinary Service (Agrodefesa), from which technical forms and protocols of veterinary diagnosis laboratories were reviewed. In most cases, samples of oral or cutaneous tissues and/or swabs were submitted for virological diagnosis by polymerase chain reaction (PCR) and/or virus isolation. Thirty seven outbreaks/cases of vesicular disease were notified in cattle of 25 counties; in 33 cases the animals presented lesions clinically compatible with poxviruses. The etiology of 25 out of 33 outbreaks/cases was confirmed as poxviruses by PCR and/or viral isolation: 13 as bovine vaccinia virus (VACV), six as pseudocowpox virus (PCPV), five as bovine papular stomatitis virus (BPSV) and one coinfection (VACV and an Orf virus-like parapoxvirus). The laboratory confirmed that cases occurred mainly in dairy cattle $(19 / 25)$ and during the dry season $(22 / 25)$. In adult cattle, gross changes were observed mainly in the teats and udder and included vesicles, ulcers, crusts, papules and scars and varied of type, severity and affected region, depending on the poxvirus species. In calves, the main lesions were ulcers in the mouth and muzzle. Zoonotic lesions compatible with poxvirus infections were observed for all diagnosed poxviruses, affecting especially the hands of milkers and other farm workers. Our data demonstrate the sanitary and economic relevance of these diseases and the wide circulation of different poxviruses in cattle from GO.
\end{abstract}

INDEX TERMS: Bovine papular stomatitis virus, diseases of cattle, poxviruses, pseudocowpox virus, VACV, cattle, Brazil.

RESUMO-- [Estudo retrospectivo de poxviroses diagnosticadas em bovinos no estado de Goiás (2010-2018).] Foi realizado um estudo retrospectivo das infecções por poxvírus diagnosticadas em bovinos do estado de Goiás (GO), entre 2010 e 2018. Todos

\footnotetext{
${ }^{1}$ Received on September 9, 2021.

Accepted for publication on September 27, 2021.

${ }^{2}$ Graduate Program in Animal Science, Universidade Federal de Goiás (UFG), Rodovia Goiânia/Nova Veneza Km 8, Campus Samambaia, Goiânia, GO 74690-900, Brazil.

${ }^{3}$ Agência Goiana de Defesa Agropecuária, Goiânia, GO, Brazil.

${ }^{4}$ Escola de Veterinária e Zootecnia, Universidade Federal de Goiás (UFG), Rodovia Goiânia/Nova Veneza Km 8, Campus Samambaia, Goiânia, G0 74690-900, Brazil.

${ }^{5}$ Departamento de Medicina Veterinária Preventiva, Universidade Federal de Santa Maria (UFSM), Av. Roraima 1000, Camobi, Santa Maria, RS 97105-000, Brazil.

${ }^{6}$ Laboratório de Diagnóstico Patológico Veterinário, Universidade de Brasília (UnB), SRB, Área Especial, Galpão 04, Granja do Torto, Brasília, DF 70636-020, Brazil. *Corresponding author: santanafjf@yahoo.com
}

os casos foram investigados pela Agência Goiana de Defesa Agropecuária (Agrodefesa). Foram revisados formulários técnicos e protocolos de laboratórios de diagnóstico veterinário. $\mathrm{Na}$ maioria dos casos, amostras de tecidos orais ou cutâneos e/ou swabs foram encaminhadas para diagnóstico virológico. Foram notificados 37 surtos/casos de doença vesicular em bovinos em 25 municípios; em 33 casos os animais apresentavam lesões clinicamente compatíveis com poxvírus. A etiologia de 25 de 33 surtos/casos foi confirmada como poxvírus por PCR e/ou isolamento viral: 13 como vírus vaccínia (VACV), seis como vírus pseudocowpox (PCPV), cinco como vírus da estomatite papular bovina (BPSV) e um caso de coinfecção (VACV e um parapoxvírus semelhante ao Orf vírus). Os casos confirmados laboratorialmente ocorreram principalmente em bovinos leiteiros $(19 / 25)$ e durante a estação seca $(22 / 25)$. Em bovinos adultos, alterações macroscópicas foram observadas principalmente nas tetas e úbere e incluíram vesículas, úlceras, 
crostas, pápulas e cicatrizes e variaram quanto ao tipo, gravidade e região afetada, dependendo da espécie do poxvírus. Em bezerros, as principais lesões foram úlceras na boca e focinho. Lesões zoonóticas compatíveis com infecção por poxvírus foram observadas em todas as poxviroses diagnosticadas, afetando principalmente as mãos dos ordenhadores e outros trabalhadores rurais. Nossos dados demonstram a relevância sanitária e econômica dessas doenças e a ampla circulação de diferentes poxvírus em bovinos de GO.

TERMOS DE INDEXAÇÃO: Vírus da estomatite popular bovina, doenças de bovinos, poxviroses, vírus pseudocowpox, VACV, bovinos, Brasil.

\section{INTRODUCTION}

Cattle's vesicular diseases are caused by a heterogeneous group of viruses. These infections present relevant sanitary and economic importance around the world, such as foot-andmouth disease (FMD), vesicular stomatitis (VS), bovine vaccinia (BV), bovine papular stomatitis (BPS), herpetic mammillitis (BHM) and pseudocowpox (PCP). Malignant catarrhal fever (MCF) and bovine viral diarrhea/mucosal disease (BVD/MD) should also be included in the differential diagnosis, since they may cause similar cutaneous, mucous and mucocutaneous lesions (Riet-Correa et al. 1996, Mauldin \& Kennedy 2016). FMD is considered the most important vesicular disease, due to the serious restrictions and economic embargoes imposed to countries/regions in which the disease occurs (Riet-Correa et al. 1996, Lubroth 2002).

Outbreaks/cases of poxvirus-associated disease have been reported in some Brazilian regions in the recent years, affecting mostly dairy cows and milkers. BV has been described in Southeastern country (Trindade et al. 2003, Leite et al. 2005, Lobato et al. 2005, Trindade et al. 2007, Schatzmayr et al. 2009), PCP and BPS in Northern (Cargnelutti et al. 2014) and Southern regions (Cargnelutti et al. 2012). In addition, cases of coinfection with two or three distinct poxviruses have also been reported in some regions (Trindade et al. 2006, Campos et al. 2011, Laguardia-Nascimento et al. 2017).

The first studies confirming infections by poxvirus in cattle from Brazilian Midwestern were published early in this century (Nagasse-Sugahara et al. 2004). Recently, an additional study performed in Distrito Federal demonstrated that vaccinia virus (VACV) is the most common poxvirus circulating in cattle in this region, followed by pseudocowpox virus (PCPV), bovine papular stomatitis virus (BPSV); cases of coinfection by PCPV and BPSV were also described (Alonso et al. 2020).

Goiás is a Brazilian Midwestern state currently holding over 22 million cattle and it is considered the fourth largest dairy producer of Brazil (IBGE 2020). In addition to the public health and economic importance, the lack of field and laboratorial data affects the knowledge about the epidemiology of these infections in the state. Furthermore, official data about the occurrence, morbidity and epidemiology of poxviruses affecting cattle in Goiás state is scarce. Thus, the current study aimed to describe the epidemiological, clinical and pathological aspects of poxviruses diagnosed in cattle in Goiás State, Brazil, during nine years (2010-2018).

\section{MATERIALS AND METHODS}

A retrospective and descriptive study of cases of bovine poxviruses diagnosed and notified in Goiás state, Brazil, between 2010 and 2018 was performed. These data were kindly provided by the Program of Animal Sanity of "Agência Goiana de Defesa Agropecuária" (Agrodefesa), from Goiás, Brazil. The cases were diagnosed by notification of farmers, veterinarians or general population to Agrodefesa (passive surveillance). After official communication, technical visits were performed in farms to investigate and confirm vesicular lesions in cattle. In addition, protocols and reports of "Laboratório de Patologia Veterinária" (LPV) of "Universidade Federal de Jataí" (UFJ), of "Laboratório de Diagnóstico Patológico Veterinário" (LDPV) of "Universidade de Brasília" (UnB) and technical forms of Agrodefesa were reviewed. These documents had detailed information about each case/outbreak occurring in Goiás, such as species, age, sex, breed, clinical signs, epidemiological data [locality, period of the year, type of activity (dairy, beef and mixed) and morbidity data], laboratorial findings, gross changes, definitive diagnosis and human involvement.

During the technical visits to farms, at least 5-8\% of the animals of the herd were clinically examined. When animals presented gross lesions compatible with poxviruses (vesicles, papules, pustules, ulcers, scabs or scars), swabs and tissue/lesion fragments (approx. $0.8 \mathrm{~cm}^{2}$ ) were collected, after physical restraint and local anesthesia (2-5mg/kg of lidocaine chloride $2 \%$ ). These samples were stored in isothermal boxes and immediately sent to the laboratory to perform virological diagnosis, where they were stored at $-80^{\circ} \mathrm{C}$. All collected cases were first evaluated by Agrodefesa veterinarians to discard a possible case of FMD or VS.

Seventeen cases were submitted to quantitative PCR in the "Laboratório de Viroses de Bovídeos" (LVB) of the "Instituto Biológico" (IB-SP), in São Paulo, Brazil, according to Silva et al. (2018). Molecular diagnosis was performed by a multiplex PCR in eight cases/outbreaks, for simultaneous detection of BPSV, PCPV, VACV and Bovine alphaherpesvirus 2 (BoHV-2) in the "Setor de Virologia" of the "Universidade Federal de Santa Maria", Santa Maria, Brazil, according to Cargnelutti et al. (2017).

This study was approved according to the Ethical Principles of Animal Care and Research and under Ethics Committee on Animal Use (CEUA) (protocol number 122/17) and by the Ethics and Research Committee (CEP) (number report 2.509.406), "Universidade Federal de Goiás", Brazil.

All form-ins (Agrodefesa) and protocols/reports from the archives of the two laboratories (LPV-UFJ and LDPV-UnB) in the above-mentioned period were reviewed. With this, information was acquired for each case/outbreak, corresponding to age, sex, clinical signs, epidemiological data (county, time of the year, type of breeding, morbidity rates), macroscopic lesions and definitive diagnosis. In addition, data referring to human exposure (milkers) who have developed similar vesicular/pustular lesions were also analyzed (number of susceptible and affected, age, sex, location and type of lesions, evolution and symptoms).

\section{RESULTS}

Thirty-seven outbreaks of vesicular disease in cattle were notified in 25 counties of Goiás state, during the monitored period; from which 25 were associated with poxvirus infections: VACV (13), PCPV (6), BPSV (5) and a coinfection by VACV/ Orf virus-like parapoxvirus (1). Eight outbreaks presented epidemiological, clinical and pathological findings compatible with poxviruses, including concomitant human infections, 
yet virological/molecular diagnosis was not performed. In addition, four other cases were interpreted as associated with mechanical/traumatic factor.

The positive cases were identified mainly in the Southern mesoregion (16/25), followed by Central (4/25), Northwestern $(3 / 25)$, Eastern $(1 / 25)$ and Northern (1/25) (Fig.1, Table 1). Figure 2 shows the distribution of these diseases per year. During the technical visits to the farms, other domestic animals (such as pigs, goats, sheep, and horses) were clinically evaluated and none presented oral and/or cutaneous lesions. Considering general data, independently of the diagnosed poxvirus, dairy cattle were more affected $(19 / 25)$, followed by mixed $(3 / 25)$ and beef $(1 / 25)$. In two cases $(2 / 25)$, the herd purpose was not informed. The positive cases were concentrated mainly in the dry season (22/25), which occurs from April to October.

Eight out of 13 outbreaks of BV were published previously (Sant'Ana et al. 2013a). Table 2 presents the epidemiological and clinical data of the additional outbreaks (five) of these poxviruses. The cases occurred in the mesoregions Center (Iporá, Ouro Verde de Goiás, Uruana), Northwestern (Santa Fé de Goiás) and Southern (Joviânia), with one outbreak in each county. Breeding systems of the farms with positive cases included three dairy and two mixed activity. Four outbreaks occurred in the dry season and another one in the rainy season.

In all outbreaks of BV, some epidemiological factors could be associated with the disease, such as the milk transport routes, trucks and people that simultaneously worked in many farms. In one outbreak, cattle presented lesions after the introduction of a new pelleted food. Cows (3-10 years) and calves (1-8 months) represented the affected categories. Gross changes consisted mainly on focal or multifocal lesions, such as ulcers $(4 / 5)$, vesicles $(3 / 5)$, crusts $(3 / 5)$ and, less commonly, macules, in the teat and udder. Ulcers restricted to the mouth, tongue or muzzle were observed in calves, with clinical course ranging from 12 to 20 days.

Cases of human infection in milkers or other farm workers were detected in three out of five outbreaks of BV, making up nine human cases. The symptoms included body pain, general malaise, headache, fever and localized lesions in hands, fingers, mouth and arms, such as ulcers and crusts.

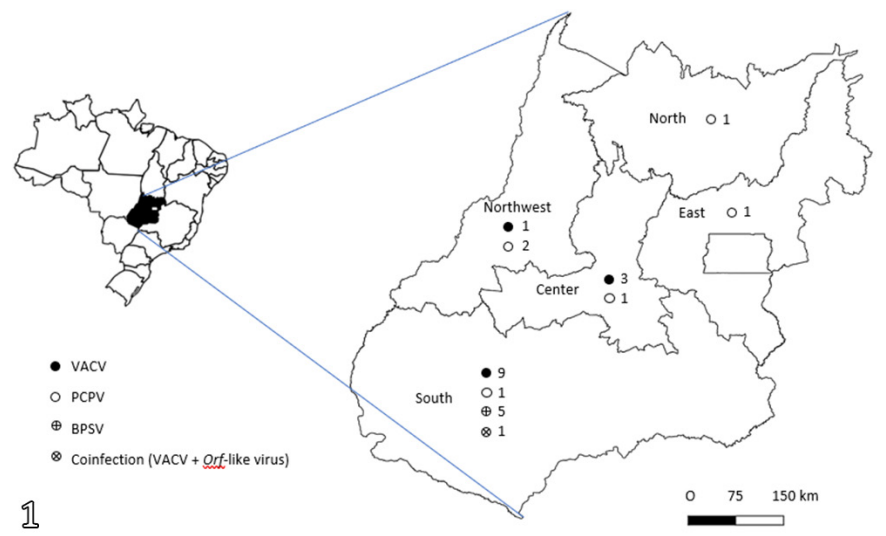

Fig.1. Poxviruses diagnosed in cattle in Goiás State, Brazil (20102018). Zoomed-in map shows the mesoregions with positive cases. Circle inside mesoregions indicate the confirmed poxviruses and number of cases. Vaccinia virus (VACV), pseudocowpox virus (PCPV), bovine papular stomatitis virus (BPSV).
In one outbreak, the farm was notified and investigated only after the affected milkers sought to medical assistance in the municipality. In this outbreak, the wife of one sick milker also presented ulcerative lesions in her mouth. In some cases, these workers remained 2-4 days away from work.

Six outbreaks of PCPV-associated disease were diagnosed in all mesoregions: two in Northwestern (São Miguel do Araguaia and Faina), one in Northern (Uruaçu), one in Center (Ceres), one in Eastern (Cocalzinho de Goiás) and another one in Southern (Piracanjuba) (Table 3). Most cases (4/6) occurred in the dry season. Three outbreaks (3/6) were diagnosed in dairy cattle affecting cows and calves, and only one case was observed in beef steers. There was no information of the breeding system in two outbreaks. Vehicles, including milk trucks, transit of workers among farms and proximity with a busy highway were implicated with possible sources of infection in one outbreak. The gross lesions observed were ulcers $(1 / 6)$, scars $(2 / 6)$ and crust $(2 / 6)$ in the teat and udder of cows and ulcers in the muzzle and mouth of calves. Multifocal ulcers affecting the gum and the ventral aspect of the tongue were detected in an outbreak in beef cattle. Human infection was observed only in one outbreak, in which the milker presented pustules in his finger after contact with affected cattle.

Four out of five outbreaks of BPS were reported previously (Sant'Ana et al. 2012). The fifth outbreak occurred in the mesoregion Southern (Jataí), in October 2014 (dry season). Only one adult cow of a farm with mixed activity presented

Table 1. Mesoregion and county distribution of 25 cases of poxviruses diagnosed in cattle, from 2010 to 2018, in the Goiás State, Brazil

\begin{tabular}{|c|c|c|c|c|}
\hline \multirow{2}{*}{ Mesoregion and county } & \multicolumn{4}{|c|}{ Number of cases } \\
\hline & VACV & PCPV & BPSV & $\mathrm{CI}$ \\
\hline \multicolumn{5}{|l|}{ Center } \\
\hline Ceres & - & 1 & - & - \\
\hline Iporá & 1 & - & - & - \\
\hline Ouro Verde de Goiás & 1 & - & - & - \\
\hline Uruanã & 1 & - & - & - \\
\hline \multicolumn{5}{|l|}{ East } \\
\hline Cocalzinho de Goiás & - & 1 & - & - \\
\hline \multicolumn{5}{|l|}{ North } \\
\hline Uruaçu & - & 1 & - & - \\
\hline \multicolumn{5}{|l|}{ Northwest } \\
\hline Faina & - & 1 & - & - \\
\hline Santa Fé de Goiás & 1 & - & - & - \\
\hline São Miguel do Araguaia & - & 1 & - & - \\
\hline \multicolumn{5}{|l|}{ South } \\
\hline Buriti Alegre & 1 & - & - & - \\
\hline Edéia & 1 & - & - & - \\
\hline Jataí & - & - & 5 & 1 \\
\hline Joviânia & 1 & - & - & - \\
\hline Mineiros & 1 & - & - & - \\
\hline Piracanjuba & - & 1 & - & - \\
\hline Pontalina & 1 & - & - & - \\
\hline São João da Paraúna & 1 & - & - & - \\
\hline Varjão & 3 & - & - & - \\
\hline TOTAL & 25 & & & \\
\hline
\end{tabular}

VACV = vaccinia virus, PCPV = pseudocowpox virus, $\mathrm{BPSV}=$ bovine papular stomatitis virus, $\mathrm{CI}=$ coinfection $\mathrm{VACV}$ and Orf virus-like parapoxvirus. 
multifocal crusted ulcers affecting udder and teat that remained by 12 days. There were no reported cases of human involvement in this outbreak.

In addition, one additional outbreak of coinfection by two poxviruses (VACV and Orf virus-like parapoxvirus) was confirmed in dairy cows associated to human infection in Jataí (Southern mesoregion). This last outbreak had been published previously (Sant'Ana et al. 2013b).

In 13 out of 37 notified cases, some of them were suspected $(5 / 13)$ and others poxviruses confirmed (8/13). The measures adopted on the farm by the local official veterinary service included temporary interdiction/closure of the farms, isolation of animals with clinical lesions and disinfection and/or cleaning of the teats.

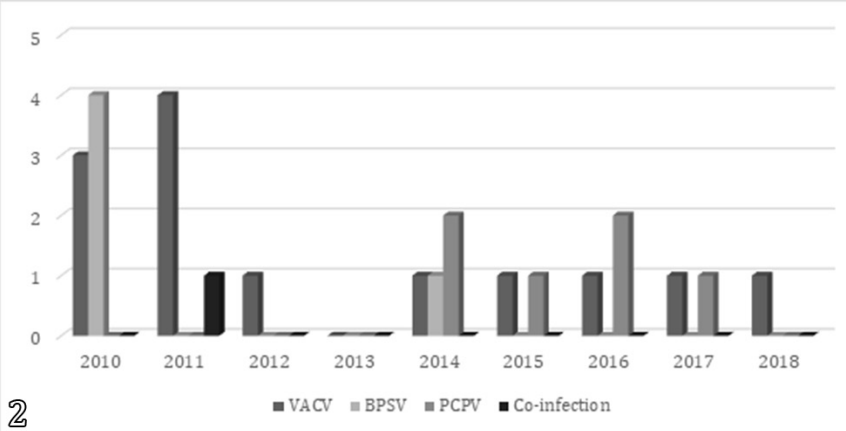

Fig.2. Number of cases according to distribution per year (2010-2018) of 25 outbreaks of poxviruses diagnosed in cattle in the Goiás state, Brazil. Vaccinia virus (VACV), bovine papular stomatitis virus (BPSV), pseudocowpoxvirus (PCPV).

\section{DISCUSSION AND CONCLUSION}

A retrospective study of cases/outbreaks of bovine poxviruses in a Brazilian midwestern State demonstrated the high importance of these viruses for dairy and beef cattle production in this region. Some cases have already been published, but due to the high relevance to the data of the study, they were included in the discussion.

The epidemiological, clinical and pathological findings of the 37 investigated notifications of vesicular and exanthematic disease in cattle were compatible with the suspicion of poxviruses, yet the virological diagnosis was confirmed in $67.57 \%$ (25/37) of the outbreaks. Eight outbreaks with highly similar epidemiological and pathological characteristics, including human infections, had no virological confirmation. Possibly, some problem related to sample collection (superficial or insufficient samples, for example) and/or conservation (inappropriate temperature, for example) may have compromised the laboratory diagnosis. In addition, other infectious diseases could be involved in these cases, such as malignant catarrhal fever, bovine viral diarrhea (mucosal disease) and BoHV-2, among others.

In the last decades, cases/outbreaks of poxvirus infections have been diagnosed in cattle in various countries, including Brazil. In this country, scattered outbreaks of these diseases affecting one or few farms have been reported, especially in Southeast region (Trindade et al. 2003, Leite et al. 2005, Lobato et al. 2005, Megid et al. 2008). A recent study demonstrated the presence of these poxviruses in cattle from a region of Brazil Midwestern, Distrito Federal. VACV was the most common poxvirus diagnosed in this region, between 2015 and 2018 (Alonso et al. 2020). For the first time, a large

Table 2. Epidemiological, clinical and pathological findings of five outbreaks of bovine vaccinia, from 2014 to 2018 , in Goiás State, Brazil

\begin{tabular}{|c|c|c|c|c|c|c|c|c|}
\hline No. & $\begin{array}{l}\text { Month/year } \\
\text { and county }\end{array}$ & Total herd & Affected herd & $\begin{array}{l}\text { Clinical course } \\
\text { (days) }\end{array}$ & $\begin{array}{l}\text { Possible source of } \\
\text { infection }\end{array}$ & $\begin{array}{c}\text { Type of } \\
\text { exploration }\end{array}$ & Gross findings & $\begin{array}{c}\text { Human } \\
\text { involvement }\end{array}$ \\
\hline 1 & $\begin{array}{l}\text { June/2014, } \\
\text { Uruanã }\end{array}$ & $\begin{array}{c}\text { Calves - } 24 \\
\text { Heifers/steers - } 15 \\
\text { Cows - } 23 \\
\text { Bulls - } 1\end{array}$ & $\begin{array}{c}\text { Calves - } 0 \\
\text { Heifers /steers - } 0 \\
\text { Cows - } 16 \text { (3-6 years) } \\
\text { Bulls - } 0\end{array}$ & 15 & $\begin{array}{l}\text { Milk trucks, transit } \\
\text { of people among } \\
\text { farms }\end{array}$ & Dairy & Dry vesicles, teat & No \\
\hline
\end{tabular}

2 August/2015, Iporá

\section{Calves - 19 Heifers/steers - 7 Cows - 34} Bulls - 1 Heifers/steers - 0 Cows - 33 (3-7 years) Bulls - 0
$\mathrm{NI}$

$$
\begin{aligned}
& \text { milk trucks, transit } \\
& \text { of people/ workers } \\
& \text { among farms }
\end{aligned}
$$

NI

Heifers/steers - 0

Cows - 10 (3-6 years) Bulls - 0

Calves - 3

Heifers/steers - 0

Cow - 30 (4-10 years)

$$
\text { Bulls - } 0
$$

Calves - 0

Heifers/steers - 0

Cows -1 (5 years) Bulls - 0

\author{
Milk trucks, transit \\ of people/ workers \\ among farms \\ Introduction of a \\ new ration \\ Milk trucks, transit \\ of people/ workers \\ between farms, \\ proximity with \\ highway
}

Mixed

Cows - Macules, vesicles, ulcers, and dark crusts, teat and udder. Calves - ulcers, mouth and muzzle

Cows - ulcers and crusts, teat. Calves - ulcers, tongue

Mixed

Cows - ulcers and crusts, teat.

Calves - ulcers, muzzle

Dairy

Vesicles and ulcers, teat and udder
Yes, two milkers

Yes, six workers and/or milkers Yes, one milker

No

$\mathrm{NI}=$ not informed. 
investigation evaluating epidemiological and pathological aspects of bovine poxviruses was performed in Goiás state using official data and results of passive surveillance in all mesoregions of the state. Considering the general data, dairy cattle was the most affected category (76\%), followed by mixed (12\%) and beef (4\%).

Out of the cases with etiologic confirmation in the current study, VACV was the most frequent poxvirus (52\%), followed by PCPV (24\%) and BPSV (20\%). Other additional cases of mixed infection by VACV and Orf virus-like parapoxvirus (4\%) were identified. A recent study performed in a neighboring Brazilian federative unit showed that the same poxvirus infect cattle of the region with very similar frequencies: $51.92 \%$ to VACV, $17.31 \%$ to PCPV, $15.38 \%$ to BPSV and $9.62 \%$ to coinfection (PCPV/BPSV) (Alonso et al. 2020). Outbreaks of bovine parapoxviruses have also been diagnosed in other Brazilian regions (Cargnelutti et al. 2012, Cargnelutti et al. 2014) and in other countries, such as United States (Moeller Jr. et al. 2018), Japan (Inoshima et al. 2009), Turkey (Şevik 2019), South Korea (Oem et al. 2013) and Bangladesh (Lederman et al. 2014).

In the current study, the positive cases were observed in all mesoregions of the state, demonstrating that these poxviruses circulate widely in the local bovine herds, but most cases were concentrated in Southern mesoregion. Similar data were detected in a study performed in a federative unit neighbor to Goiás (Alonso et al. 2020). Probably, highest notification of cases in the southern mesoregion occurred because this zone is one of the regions with the highest dairy productivity in the state. In the last years, the southern and eastern mesoregions had the greatest growth in the dairy activity, and the central and southern regions were the ones that obtained the greatest productivity per cow between
2002 and 2011 (Silva \& Silva 2014). Other important aspect is the frequent circulation and transport of cattle from other neighboring states to Goiás, such as Minas Gerais, Bahia, São Paulo and Distrito Federal, where spontaneous outbreaks of these poxviruses were notified in the last decades (Lobato et al. 2005, Assis et al. 2015, Laguardia-Nascimento et al. 2017, Alonso et al. 2020).

For all poxviruses, a high number of cases was observed during the dry season. Probably, this seasonal trend is related to higher risk of trauma in the teats in dry season, due to the dryness of the skin (Lobato et al. 2005, Assis et al. 2015). BV was diagnosed in three mesoregions, but predominantly in Southern. Most cases was observed in dairy cattle (11/13) in the dry season (12/13), as detected by other (Leite et al. 2005, Lobato et al. 2005, Assis et al. 2015, Silva et al. 2018, Alonso et al. 2020). The clinical course varied of 12 to 45 days and the lesions consisted mainly of vesicles, ulcers and crusts affecting the teat and udder of cows. In calves, crusted ulcerative lesions predominated in muzzle and mouth (palate and gum). In eleven outbreaks (11/13), milkers that had close contact with the affected animals developed concomitant vesicular disease. Very similar clinical and pathological findings were also detected previously in cattle and humans of other regions (Trindade et al. 2003, Lobato et al. 2005, Schatzmayr et al. 2009). In a recent study, cows and heifers presented predominantly VACV-associated oral lesions (Alonso et al. 2020) and, occasionally, vulvar papular lesions have been described in cows infected by VACV (Moeller Jr. et al. 2018, Alonso et al. 2020).

The transit of milk trucks among farms and people that simultaneously worked in many affected farms were considered important risk factors to $\mathrm{BV}$ in our study, as noticed previously (Lobato et al. 2005). Other studies have

Table 3. Epidemiological, clinical and pathological findings of outbreaks of pseudocowpox virus (PCPV), from 2010 to 2018 , in the Goiás State, Brazil

\begin{tabular}{|c|c|c|c|c|c|c|c|c|}
\hline No. & $\begin{array}{l}\text { Month/year } \\
\text { and county }\end{array}$ & Total herd & Affected herd & $\begin{array}{l}\text { Clinical course } \\
\text { (days) }\end{array}$ & $\begin{array}{l}\text { Possible source } \\
\text { of infection }\end{array}$ & $\begin{array}{c}\text { Type of } \\
\text { exploration }\end{array}$ & Gross findings & $\begin{array}{c}\text { Human } \\
\text { involvement }\end{array}$ \\
\hline 1 & $\begin{array}{l}\text { July } / 2014, \\
\text { São Miguel do } \\
\text { Araguaia }\end{array}$ & NI & NI & $\mathrm{NI}$ & NI & NI & NI & NI \\
\hline 2 & $\begin{array}{c}\text { September/2014, } \\
\text { Uruaçu }\end{array}$ & $\begin{array}{c}\text { Calves - } 123 \\
\text { Heifers/steers - } 720 \\
\text { Cows - } 0 \\
\text { Bulls - } 22\end{array}$ & $\begin{array}{c}\text { Calves - } 0 \\
\text { Heifers - } 0 \\
\text { Steers - } 2 \\
\text { Cows - } 0 \\
\text { Bulls - } 0\end{array}$ & 7 & NI & Beef & $\begin{array}{l}\text { Ulcers, gum and } \\
\text { tongue (ventral } \\
\text { aspect) }\end{array}$ & No \\
\hline 3 & $\begin{array}{l}\text { January/2015, } \\
\text { Cocalzinho de } \\
\text { Goiás }\end{array}$ & NI & NI & NI & NI & NI & NI & NI \\
\hline 4 & $\begin{array}{c}\text { October/2016, } \\
\text { Faina }\end{array}$ & $\begin{array}{c}\text { Calves - } 16 \\
\text { Heifers/steers - } 10 \\
\text { Cows - } 34 \\
\text { Bulls - } 1\end{array}$ & $\begin{array}{c}\text { Calves - } 5 \\
\text { Heifers /steers - } 0 \\
\text { Cow - } 8 \text { (4-10 years }) \\
\text { Bulls - } 0\end{array}$ & 30 & Milk trucks & Dairy & $\begin{array}{c}\text { Cows - ulcers and } \\
\text { crusts, udder and teat. } \\
\text { Calves - ulcers, muzzle } \\
\text { and mouth }\end{array}$ & $\begin{array}{l}\text { Yes, one } \\
\text { milker } \\
\text { (pustule in } \\
\text { finger) }\end{array}$ \\
\hline 5 & $\begin{array}{l}\text { December/2016, } \\
\text { Piracanjuba }\end{array}$ & $\begin{array}{c}\text { Calves - } 3 \\
\text { Heifers/steers - } 5 \\
\text { Cows - } 5 \\
\text { Bulls - } 0\end{array}$ & $\begin{array}{c}\text { Calves - } 0 \\
\text { Heifers } / \text { steers - } 0 \\
\text { Cows }-1 \text { ( } 6 \text { years }) \\
\text { Bulls - } 0\end{array}$ & 15 & NI & Dairy & Crusts and scars, teat & No \\
\hline 6 & $\begin{array}{l}\text { July/2017, } \\
\text { Ceres }\end{array}$ & $\begin{array}{c}\text { Calves - } 16 \\
\text { Heifers/steers - } 8 \\
\text { Cows - } 18 \\
\text { Bulls - } 0\end{array}$ & $\begin{array}{c}\text { Calves - } 0 \\
\text { Heifers } / \text { steers - } 0 \\
\text { Cows }-1 \text { ( } 8 \text { years }) \\
\text { Bulls - } 0\end{array}$ & 8 & $\begin{array}{l}\text { Vehicles, transit } \\
\text { of workers, } \\
\text { proximity with } \\
\text { highway }\end{array}$ & Dairy & Crusts and scars, teat & No \\
\hline
\end{tabular}

$\mathrm{NI}=$ not informed. 
noted a relation between VACV infection and the probable transmission of the virus in milk tanks (Lobato et al. 2005) and waste transportation to a public collection site (Peres et al. 2013). According to a study performed in Amazon biome investigating the causes of VACV outbreaks in the region, the main cause of the spread of viruses at a distance was the movement of animals, while the migration of dairy workers was involved in focal dissemination (Quixabeira-Santos et al. 2011).

Humans, mainly milkers (in some cases, their close relatives), presented classic poxvirus lesions in 11 out of 13 outbreaks of VACV, comprising 20 affected people. Main symptoms included painful lesions in the hands, neck and face. Similar symptoms have been described in other outbreaks with human involvement (Nagasse-Sugahara et al. 2004, Megid et al. 2008, Silva et al. 2008, Schatzmayr et al. 2009). In comparison with other zoonotic vesicular diseases, BV appears to affect more severely humans having contact with affected cattle (Büttner \& Rziha 2002, Silva-Fernandes et al. 2009). In the current study, the affected milkers stayed two or four days out of work under medical care. Horizontal transmission between humans had already been reported (Lobato et al. 2005, Batista et al. 2009, Oliveira et al. 2014), and was identified in two outbreaks of this study.

PCPV infection was the unique poxvirus diagnosed in all mesoregions of the state. The disease occurred predominantly in the dry season, specially affecting dairy cows and, less frequently, calves and steers. Gross changes included ulcerative and crusted lesions in the teat and udder of cows and oral ulcers in calves. Similar lesions have been observed in other investigations (Cargnelutti et al. 2014, Lederman et al. 2014). In some cases, chronic inter-digital ulcerative changes can occur (Alonso et al. 2020). In addition, ulcers affecting the gum and tongue of beef steers were noted in an outbreak of the current study.

There was only one outbreak with PCPV-associated human cases. Zoonotic lesions caused by bovine parapoxviruses appear to be less severe comparing with VACV. Usually, local injuries on the hands and fingers which can be aggravated by secondary bacterial infection are observed (Büttner \& Rziha 2002, Lemos \& Riet-Correa 2007).

In the current study, the five outbreaks of BPS were diagnosed in a same county (Jataí) of the Southern mesoregion, during the dry season, in 2010 and 2014. Dairy cows were affected in all outbreaks and presented painful papular and ulcerative lesions, mainly on the teats. Usually, this disease is more common in calves and the lesions consist of papules (often ulcerative) on the muzzle, lips and mouth (Brown et al. 2007, Oem et al. 2013, Alonso et al. 2020).

BPS is considered a disease of low sanitary relevance by some authors (Brown et al. 2007). Nevertheless, in four out five outbreaks of this study the infection was economically important, because promoted a decrease in milk production and interruption of the lactation in the herds. In Northern Brazil, some risk factors for BPSV and PCPV infections were observed, such as free circulation among cattle of some farms, early age of the affected animals (less than six months) and the management of animals acquired from different farms together (Cargnelutti et al. 2014).

Human cases with similar lesions in the hands were detected in four out of five outbreaks of BPS. Nodules and pustules on the hands can be observed in infected people (Bowman et al. 1981, Alonso et al. 2020). Additionally, regional lymphadenitis, fever and general malaise may be observed in occasional cases (Alonso et al. 2020).

Sporadic cases of coinfection by two or three poxviruses have been described in cattle (Laguardia-Nascimento et al. 2017, Alonso et al. 2020). One mixed infection by two distinct poxviruses (VACV and Orf virus-like parapoxvirus) was identified in our study, mainly in dairy cows from the Southern mesoregion. The animals presented numerous vesicles, painful papules and scabby proliferative lesions in the teats and udder. Milker's involvement was also identified in this outbreak. Very similar epidemiological findings and lesions were observed previously in cows in a coinfection by PCPV and BPSV (Alonso et al. 2020). Coinfections by distinct poxvirus have been confirmed also affecting horses in Southern Brazil (Campos et al. 2011) and humans in Southeast Brazil (Abrahão et al. 2010).

In all cases evaluated of this study, the diagnosis of poxvirus was established by PCR and, in some cases, additionally by virus isolation. Other complementary techniques can help the diagnosis of these viruses, such as histopathology (Alonso et al. 2020), serology (Mota et al. 2010, Franco-Luiz et al. 2014, Borges et al. 2017) and electronic microscopy (Trindade et al. 2003, Leite et al. 2005, Schatzmayr et al. 2009, Brum et al. 2010).

Possibly, more cases occur in field situations and the notifications are not informed clearly and directly to the local official veterinary service. The diagnosis and notification of these diseases is reinforced, for greater control and consequently less dissemination of these diseases. It is noteworthy that after diagnosis, hygiene measures and temporary interdiction of farms are generally carried out, so that we can thus reduce the spread of the disease between the farms and the animals.

Authors' contributions.- All authors made substantial contributions to the interpretation of data. L.F. Silva wrote the first version of the manuscript and the others authors approved the final version to be published.

Acknowledgements.- We are grateful to the veterinary team from Agrodefesa for their excellent technical support and "Coordenação de Aperfeiçoamento de Pessoal de Nível Superior" (CAPES) for the PhD scholarship of the first author. Financial support was provided by "Fundação de Apoio à Pesquisa do Distrito Federal" (FAP-DF) (Grant 0193.001584/2017). E.F. Flores is a "Conselho Nacional de Desenvolvimento Científico e Tecnológico" (CNPq) research fellow.

Conflict of interest statement.- The authors declared no potential conflicts of interest with respect to the research, authorship, and/or publication of this article.

\section{REFERENCES}

Abrahão J.S., Silva-Fernandes A.T., Assis F.L., Guedes M.I., Drumond B.P., Leite J.A., Coelho J.F.L., Turrini F., Fonseca F.G., Lobato Z.I.P., Madureira M., Ferreira P.C., Bonjardim C.A., Trindade G.S. \& Kroon E.G. 2010. Human vaccinia virus and pseudocowpox virus co-infection: clinical description and phylogenetic characterization. J. Clin. Virol. 48(1):69-72. <https:// dx.doi.org/10.1016/j.jcv.2010.02.001><PMid:20207192>

Alonso R.C., Moura P.P., Caldeira D.F., Mendes M.H.A.F., Pinto M.H.B., Cargnelutti J.F., Flores E.F. \& Sant'Ana F.J.F. 2020. Poxviruses diagnosed in cattle from Distrito Federal, Brazil (2015-2018). Transbound. Emerg. Dis. 67(1):15631573. <https://dx.doi.org/10.1111/tbed.13490> <PMid:31971341>

Assis F.L., Franco-Luiz A.P.M., Paim L.M., Oliveira G.P., Pereira A.F., Almeida G.M.F., Figueiredo L.B., Tanus A., Trindade G.S., Ferreira P.P., Kroon E.G. 
\& Abrahão J.S. 2015. Horizontal study of vaccinia virus infections in an endemic area: epidemiologic, phylogenetic and economic aspects. Arch. Virol. 160(11):2703-2708. <https://dx.doi.org/10.1007/s00705-0152549-1><PMid:26239343>

Batista V.H., Scremin J., Aguiar L.M. \& Schatzmayr H. 2009. Vulvar infection and possible human-to-human transmission of bovine poxvirus disease - Case report. Virus Rev. Res. 14(1):1-10. <https://dx.doi.org/10.17525/ VRR.V14I1.27>

Borges I.A., McCollum A.M., Mehal J.M., Haberling D., Dutra L.A.L., Vieira F.N., Andrade L.A.O., Kroon E.G., Holman R.C., Reynolds M.G. \& Trindade G.S. 2017. Dairy production practices and associated risks for bovine vaccinia exposure in cattle, Brazil. New Microbes New Infect. 20(C):43-50. <https:// dx.doi.org/10.1016/j.nmni.2017.08.004>

Bowman K.F., Barbery R.T., Swango L.J. \& Schnurrenberger P.R. 1981. Cutaneous form of bovine papular stomatits in man. J. Am. Med. Assoc. 246(24):2813-2818. <PMid:6273605>

Brown C.C., Baker D.C. \& Barker I.K. 2007. Alimentary system, p.1-296. In: Maxie M.G. (Ed.), Jubb, Kennedy, and Palmer's Pathology of Domestic Animals. W.B. Saunders, Edinburgh.

Brum M.C.S., Dos Anjos B.L., Nogueira C.E.W., Amaral L.A., Weiblen R. \& Flores E.F. 2010. An outbreak of orthopoxvirus-associated disease in horses in southern Brazil. J. Vet. Diagn. Invest. 22(1):143-147. <https://dx.doi. org/10.1177/104063871002200132><PMid:20093706>

Büttner M. \& Rziha H.J. 2002. Parapoxviruses: from the lesion to the viral genome. J. Vet. Med. B, Infect. Dis. Vet. Public Health. 49(1):7-16.<https:// dx.doi.org/10.1046/j.1439-0450.2002.00539.X> <PMid:11911596>

Campos R.K., Brum M.C.S., Nogueira C.E.W., Drumond B.R., Alves P.A., SiqueiraLima L., Assis F.L., Trindade G.S., Bonjardim C.A., Ferreira P.C., Weiblen R., Flores E.F., Kroon E.G. \& Abrahão J.S. 2011. Assessing the variability of Brazilian vaccinia virus isolates from a horse exanthematic lesion: coinfection with distinct viruses. Arch. Virol. 156(2):275-283. <https:// dx.doi.org/10.1007/s00705-010-0857-z><PMid:21080203>

Cargnelutti J.F., Flores M.M., Teixeira F.R.M., Weiblen R. \& Flores E.F. 2012. An outbreak of pseudocowpox in fattening calves in southern Brazil. J. Vet. Diagn. Invest. 24(2):437-441. <https://dx.doi.org/10.1177/1040638711435408> <PMid:22362537>

Cargnelutti J.F., Santos B.S., Lebre S.N., Sodré D.N.A., Silva R.M., Weiblen R. \& Flores E.F. 2014. Pseudovaríola e estomatite papular em bovinos no Estado de Rondônia, Brasil. Ciência Rural 44(3):479-485. <https://dx.doi. org/10.1590/S0103-84782014000300015>

Cargnelutti J.F., Weiblen R. \& Flores E.F. 2017. A multiplex PCR for viruses associated with exanthematic and vesicular disease in cattle. J. Virol. Methods 239:38-41. <https://dx.doi.org/10.1016/j.jviromet.2016.10.008> $<$ PMid:27793645>

Franco-Luiz A.P.M., Fagundes-Pereira A., Costa G.B., Alves P.A., Oliveira D.B., Bonjardim C.A., Ferreira P.C.P., Trindade G.S., Panei C.J., Galosi C.M., Abrahão J.S. \& Kroon E.G. 2014. Spread of vaccinia virus to cattle herds, Argentina, 2011. Emerg. Infect. Dis. 20(9):1576-1578. <https://dx.doi.org/10.3201/ eid2009.140154><PMid:25153340>

IBGE 2020. Instituto Brasileiro de Estatística e Geografia. Available at <https:// www.ibge.gov.br/> Accessed on Nov. 5, 2020.

Inoshima Y., Nakane T. \& Sentsui H. 2009. Severe dermatitis on cattle teats caused by bovine papular stomatitis virus. Vet. Rec. 164(10):311-312. <https://dx.doi.org/10.1136/vr.164.10.311-b><PMid:19270325>

Laguardia-Nascimento M., Oliveira A.P.F., Azevedo I.C., Rivetti Júnior A.V., Camargos M.F. \& Fonseca Júnior A.A. 2017. Spread of poxviruses in livestock in Brazil associated with cases of double and triple infection. Arch. Virol. 162(9):2797-2801. <https://dx.doi.org/10.1007/s00705-017-3407-0> $<$ PMid:28516287>

Lederman E., Khan S.U., Luby S., Zhao H., Braden Z., Gao J., Karem K., Damon I., Reynolds M. \& Li Y. 2014. Zoonotic parapoxviroses detected in symptomatic cattle in Bangladesh. BMC Res. Notes 7:816.<https://dx.doi. org/10.1186/1756-0500-7-816><PMid:25410770>

Leite J.A., Drumond B.P., Trindade G.S., Lobato Z.I.P., Fonseca F.G., Santos João R., Madureira M.C., Guedes M.I.M.C., Ferreira J.M.S., Bonjardim C.A., Ferreira P.C.P. \& Kroon E.G. 2005. Passatempo virus, a vaccinia virus strain, Brazil. Emerg. Infect. Dis. 11(12):1935-1941. <https://dx.doi.org/10.3201/ eid1112.050773><PMid:16485483>

Lemos R.A.A. \& Riet-Correa F. 2007. Infecções víricas da pele do úbere em bovinos, p.147-152. In: Riet-Correa F., Schild A.L., Lemos R.A.A. \& Borges J.R.J. (Eds), Doenças de Ruminantes de Equinos. 3aㅡ ed. Pallotti Editora, Santa Maria.

Lobato Z.I.P., Trindade G.S., Frois M.C.M., Ribeiro E.B.T., Dias G.R.C., Teixeira B.M., Lima F.A., Almeida G.M.F. \& Kroon E.G. 2005. Surto de varíola bovina causada pelo vírus vaccinia na região da Zona da Mata Mineira. Arq. Bras. Med. Vet. Zootec. 57(4):423-429. <https://dx.doi.org/10.1590/S010209352005000400001>

Lubroth J. 2002. Foot-and-mouth disease: a review for the practitioner. Vet. Clin. N. Am., Food Anim. Pract. 18(3):475-499. <https://dx.doi.org/10.1016/ s0749-0720(02)00036-1><PMid:12442579>

Mauldin E.A. \& Kennedy P. 2016. Integumetary system, p.509-736. In: Maxie M.G. (Ed.), Jubb, Kennedy and Palmer's Pathology of Domestic Animals. 6th ed. Elsevier, Missouri.

Megid J., Appolinário C.M., Langoni H., Pituco E.M. \& Okuda L.H. 2008. Vaccinia virus in humans and cattle in southwest region of São Paulo State, Brazil. Am. J. Trop. Med. Hyg. 79(5):647-651. <https://dx.doi.org/10.4269/ ajtmh.2008.79.647><PMid:18981497>

Moeller Jr. R.B., Crossley B., Adaska J.M., Hsia G., Kahn R. \& Blanchard P.C. 2018. Parapoxviral vulvovaginitis in Holstein cows. J. Vet. Diagn. Invest. 30(3):464-467. <https://dx.doi.org/10.1177/1040638718758829> <PMid:29429402>

Mota B.E.F., Trindade G.S., Diniz T.C., Silva-Nunes M., Braga E.M., UrbanoFerreira M., Rodrigues G.O.L., Bonjardim C.A., Ferreira P.C.P. \& Kroon E.G. 2010. Seroprevalence of orthopoxvirus in an Amazonian rural village, Acre, Brazil. Arch. Virol. 155(7):1139-1144. <https://dx.doi.org/10.1007/ s00705-010-0675-3><PMid:20428903>

Nagasse-Sugahara T.K., Kisielius J.J., Ueda-Ito M., Curti S.P., Figueiredo C.A., Cruz A.S., Silva M.M.J., Ramos C.H., Silva M.C.C., Sakurai T. \& Salles-Gomes L.F. 2004. Human vaccinia-like outbreaks in São Paulo and Goiá States, Brazil: virus detection, isolation and identification. Revta Inst. Med. Trop. São Paulo 46:315-322.<https://dx.doi.org/10.1590/S0036-46652004000600004>

Oem J.-K., Lee E.-Y., Lee K.-K., Kim S.-H., Lee M.-H. \& Hyun B.-H. 2013. Bovine papular stomatitis virus (BPSV) infections in korean native cattle. J. Vet. Sci. 75(5):675-678. <https://dx.doi.org/10.1292/jvms.12-0312> $<$ PMid:23292127>

Oliveira G.P., Fernandes A.T.S., Assis F.L., Alves P.A., Luiz A.P.M.F., Figueiredo L.B., Almeida C.M.C., Travassos C.E.P.F., Trindade G.S., Abrahão J.S. \& Kroon E.G. 2014. Short report: intrafamilial transmission of vaccinia virus during a bovine vaccinia outbreak in Brazil: a new insight in viral transmission chain. Am. J. Trop. Med. Hyg. 90(6):1021-1023. <https://dx.doi.org/10.4269/ ajtmh.13-0621><PMid:24615135>

Peres M.G., Bacchiega T.S., Appolinário C.M., Vicente A.F., Allendorf S.D., Antunes J.M.A.P., Moreira A.S., Legatti E., Fonseca C.R., Pituco E.M., Okuda L.H., Pantoja J.C.F., Ferreira F. \& Megid J. 2013. Serological study of vaccinia virus reservoirs in areas with and without official reports of outbreaks in cattle and humans in São Paulo, Brazil. Arch. Virol. 158(12):2433-2441. <https://dx.doi.org/10.1007/s00705-013-1740-5> <PMid:23760628>

Quixabeira-Santos J.C., Medaglia M.L.G., Pescador C.A. \& Damaso C.R. 2011. Animal movement and establishment of vaccinia virus Cantagalo strain in Amazon biome, Brazil. Emerg. Infect. Dis. 17(4):726-729. <https://dx.doi. org/10.3201/eid1704.101581> <PMid:21470472> 
Riet-Correa F., Moojen V., Roehe P.M. \& Weiblen R. 1996. Viroses confundíveis com febre aftosa. Ciência Rural 26(2):323-332. <https://dx.doi.org/10.1590/ S0103-84781996000200027>

Sant'Ana F.J.F., Leal A.A., Rabelo R.E., Vulcani V.A.S., Ferreira Junior J.A., Cargnelutti J.F. \& Flores E.F. 2013a. Outbreaks of vesicular disease caused by vaccinia virus in dairy cattle from Goiás State, Brazil (2010-2012). Pesq. Vet. Bras. 33(7):860-866. <https://dx.doi.org/10.1590/S0100736X2013000700006>

Sant'Ana F.J.F., Leal F.A.A., Rabelo R.E., Vulcani V.A.S., Moreira Jr. C.A., Cargnelutti J.F. \& Flores E.F. 2013b. Coinfection by vaccinia virus and an orf viruslike parapoxvirus in an outbreak of vesicular disease in dairy cows in midwestern Brazil. J. Vet. Diagn. Invest. 25(2):267-272. <https://dx.doi. org/10.1177/1040638713475799><PMid:23404478>

Sant'Ana F.J.F., Rabelo R.E., Vulcani V.A.S., Cargnelutti J.F. \& Flores E.F. 2012. Bovine papular stomatitis affecting dairy cows and milkers in midwestern Brazil. J. Vet. Diagn. Invest. 24(2):442-445. <https://dx.doi. org/10.1177/1040638711434799><PMid:22362531>

Schatzmayr H.G., Costa R.V.C., Gonçalves M.C.R., Barreto D.F., Batista V.H., Silva M.E.V., Brust L.A.C. \& Barth O.M. 2009. Infecções humanas causadas por poxvirus relacionados ao vírus vaccinia no Brasil. Revta Soc. Bras. Med. Trop. 42(6):672-676. <https://dx.doi.org/10.1590/S0037-86822009000600012>

Şevik M. 2019. Orf virus circulation in cattle in Turkey. Comp. Immunol. Microbiol. Infect. Dis. 65:1-6. <https://dx.doi.org/10.1016/j.cimid.2019.03.013> $<$ PMid:31300096>

Silva A.C., Reis B.B., Ricci Junior J.E.R., Fernandes F.S., Corrêa J.F. \& Schatzmayr H.G. 2008. Infecção em humanos por varíola bovina na microrregião de Itajubá, Estado de Minas Gerais: relato de caso. Revta Soc. Bras. Med. Trop. 41(5):507-511.<https://dx.doi.org/10.1590/S0037-86822008000500015>
Silva M.F. \& Silva A.C. 2014. Análise da produtividade do rebanho leiteiro no estado de Goiás. Revta Bras. Agropec. Sustent. 4(2):66-74. <https:// dx.doi.org/10.21206/rbas.v4i2.260>

Silva T.G., Lima M.S., De Castro A.M.M.G., Martins M.S.N., Castiglioni V.C., Fava C.D., Okuda L.H. \& Pituco E.M. 2018. Bovine vaccinia in dairy cattle and suspicion of vesicular disease on milkers in Brazil. Ciência Rural 48(6):e20180723. <https://dx.doi.org/10.1590/0103-8478cr20170723>

Silva-Fernandes A.T., Travassos C.E.P.F., Ferreira J.M.S., Abrahão J.S., Rocha E.S.O., Viana-Ferreira F., Santos J.R., Bonjardim C.A., Ferreira P.C.P. \& Kroon E.G. 2009. Natural human infections with vaccinia virus during bovine vaccinia outbreaks. J. Clin. Virol. 44(4):308-313. <https://dx.doi. org/10.1016/j.jcv.2009.01.007> <PMid:19243990>

Trindade G.S., Drumond B.P., Guedes M.I.M.C., Leite J.A., Mota B.E.F., Campos M.A., Fonseca F.G., Nogueira M.L., Lobato Z.I.P., Bonjardim C.A., Ferreira P.C.P. \& Kroon E.G. 2007. Zoonotic vaccinia virus infection in Brazil: clinical description and implications for health professionals. J. Clin. Microbiol. 45(4):1370-1372. <https://dx.doi.org/10.1128/JCM.0092006> <PMid:17287326>

Trindade G.S., Fonseca F.G., Marques J.T., Nogueira M.L., Mendes L.C.N., Borges A.S., Peiró J.R., Pituco E.M., Bonjardim C.A., Ferreira P.C.P. \& Kroon E.G. 2003. Araçatuba virus: a vaccinia-like virus associated with infection in humans and cattle. Emerging Infect. Dis. 9(2):155-160. <https://dx.doi. org/10.3201/eid0902.020244><PMid:12603984>

Trindade G.S., Lobato Z.I.P., Drumond B.P., Leite J.A., Trigueiro R.C., Guedes M.I.M.C., Fonseca F.G., Santos J.R., Bonjardim C.A., Ferreira P.C.P. \& Kroon E.G. 2006. Short report: Isolation of two vaccinia virus strains from a single bovine vaccinia outbreak in rural area from Brazil: Implications on the emergence of zoonotic orthopoxviruses. Am. J. Trop. Med. Hyg. 75(3):486-490. <PMid:16968926> 